\title{
Analysis of the Potential Use of Social Networking for the Success of Strategic Business Planning in Small and Medium-Sized Enterprises
}

\section{Yong Dirgiatmo}

Faculty of Economics and Business, Sebelas Maret University, Surakarta the Republic of Indonesia y_dirgiatmo@yahoo.com

\author{
Doi:10.5901/mjss.2015.v6n2s2p233
}

\begin{abstract}
The availability of information technology in supporting small and medium-sized enterprises (SMEs), especially in developing countries, to improve the business performance and overcome the business problem is an interesting issue to be revealed and analyzed. Social networks like Facebook, Twitter, Youtube, blogs, etc. which today can be said as a media to promote and sell products and services for any type and scale of business, seems still not to be used optimally by SMEs. Classical problems such as financial aspects, human resources, marketing and technology are obstacles that unable to be solved completely by SMEs. This study is an experimental study that attempt to raise the issue of the social networking model that can help SMEs in making strategic business plan to be success. The purpose of this study is to investigate the existing problems, provide treatments, observe, examine and analyze the extent to which SMEs use social networking in order to formulate a successful strategic business plan. The data sample is SMEs which already utilizing social networking but not optimal or SMEs that had never utilize social networking to develop strategic business plans. The selected samples is about 25-30 associations, clusters, cooperatives, associations of craftsmen or similar businesses which are chosen purposively. The location of research is 6 districts and 1 municipality (totally $5.667 \mathrm{~km} 2$ ) in the residential of Surakarta, Central Java. The results of the first phase of research obtained from the field indicate that the majority of SMEs surveyed have not made social networking as an effective medium to assist in strategic business planning. The main cause is due to geographical location constraints, especially telecommunications infrastructure, human resources dealing with doubt and uncertainty as to the success of information technology investment to be used.
\end{abstract}

Keywords: SMEs, social networking, promotion media, strategic business planning

\section{Background}

Nowadays, the role of social media which is mediated by the Internet can support small and medium enterprises (SMEs) to gain an edge in competing (competitive advantage). Media or social networks such as Facebook, Twitter, Google+ and others have been able to create a community that connects entrepreneurs and consumers who are interested in the products or services offered, extend the coverage to overseas markets (global market), maximize return on investment, measure sentiment purchaser of the product or service through the data/information entered, manage brand reputation, products, and services and identify existing opportunities, accelerate trade traffic that occurs between the seller and the buyer (by optimizing search engines such as Google, Yahoo, etc.), and improve employee productivity by collaborating, sharing ideas about the success of projects, products, or services.

Research conducted by Hourali et al. (2008) in Ghazi \& Khalid (2012) stated that the Internet and e-business is seen by the government in various countries in the world as a strategic technology in supporting the development of SMEs. In other word, the existence of social media could also be involved in the business process and capable of being one of the strategic business planning tools to achieve the business success of an SME.

Technically, SMEs in fact realize that information technology is something necessary and important, but there is a doubt to invest in information processing devices which requires not few of costs, meanwhile the result and its effects cannot be perceived directly. For instance, the availability of company's web sites to introduce products or services to public are still as an unpredicted matters to be succeed or profitable for the company.

Some studies related to efforts to reduce the gap and overcome the lack of resources and business planning techniques that can be used by SMEs has been widely published and recommended (Curtis, 1983; Rockart, et al., 1985; Webster et al., 1989; Porter, 1998; Pollack, 2010). Similarly, research related to how or what factors can bring success for strategic business planning, including planning for enterprise information systems has been expressed by previous investigators. Martin (1989), Baets (1992), Ward \& Peppard (2002) and Brumec \& Vrcek (2002) stated that one of the 
critical factors of success in business was the strategic alignment between the company's business strategy, strategic information systems and information technology used by the company. In his book, Martin (2005) also mentioned explicitly that the company's decision related to information systems should be in-line with the business strategy of the company. Nonetheless, the atmosphere of strategic business planning is not easy to be implemented in SMEs due to the environmental characteristics of SMEs which is generally only for short-term goals, unstructured, not comprehensive and informal nature; also their lack of understanding in terms of management time when strategic business planning is conducted, skills of how to make a plan, and how to explore and empower the sources of information for the company (Cheng, 1990). Moreover, the fact that some of the methods or techniques suggested in strategic business planning is not always suitable and relevant to be adopted and implemented by SMEs (Curtis, 1983; Webster et al., 1989 in Tan, et al., 1995).

With regard to the availability of information technology which is able to bridge the limitations of the SME business climate with its business environment, the social network enable SMEs to compete with its competitors in the market both local, national and international. Griggs and Wild (2012) stated that social networks which are mediated by computer is a relatively new phenomenon and capable to evolve broadly to apply to a wide range of interests in the future.

\section{Problem Formulation}

From the above background, the study sought to map out the problems that occur in SMEs regarding the use of social networking, to explore the potential/ opportunities that are available to be developed based on the capabilities of SMEs, and to find a way or a suitable model, relevant, easy and cheap for SMEs. Next, to make strategic business planning as well to eliminate or remove doubts and lack of conviction SMEs in utilizing social networks to achieve its business objectives.

Problems in this study can be formulated in the following research questions:

1. Does the company with the size of SMEs utilized social networking for their strategic business planning? If not, why?

2. To what extent does social networking be an effective tool and contribute significantly to the success of strategic business planning for SMEs?

3. What critical factors determines the success (or failure) of social networking application in support of strategic business planning for SMEs?

4. What kind of model can be used by SMEs in utilizing social networks which support the success of strategic business planning?

\section{Research Objectives}

1. To identify the problems that occur in SMEs with regard to strategic business planning.

2. To observe the effectiveness of processes, tools and techniques used for strategic business planning done by SMEs using social networking.

3. To find the critical success (failed) factors in using social networking to support strategic business planning conducted by SMEs.

4. To propose a methodological framework and model that is compatible to the SMEs in making the strategic business plan using social networking.

\section{Significance}

It has been a lot of research and previous studies conducted with regard to the success of the company's strategic business plan and not a few methods / analysis has been recommended to be implemented in various types of companies in order to achieve business success. Nonetheless, the company with the scale of SMEs seems to have not participated fully enjoy the success of its business due to a lack of resources. Today the use of social networking as a medium for the dissemination of information, collaboration, creating a social community, and feedback of knowledge in various fields has been a remarkable phenomenon in the world of business and non-business. However, the comprehensive study of this issue is still not much explored, especially for SMEs. On another side, a question on how effective a social network can be one of strategic business planning model for SMEs is not clearly answered. Therefore, the existence of social networking model that brings success in company's strategic business planning, especially SMEs, is a very important, unique and interesting issue to study. 


\section{Literature Review}

Kau (1988), Cheng (1990), Tan, et al., (1995), Houralli, et al., (2008) stated in his study that the productivity, management skills, expertise in marketing of products or services, and use of technology (including information technology ) owned by SMEs are generally lagging behind in comparison with the bigger company or industry especially from foreign competitors. It is actually a classic problem often faced by SMEs such as limited resources both human, physic and especially financial. Efforts to curb this problem and eliminate the gap has been proposed and recommended way out by several studies done by Martin (1989), Baets (1992), Ward \& Peppard (2002), Brumec \& Vrcek (2002), and Martin (2005). In his paper, Martin (2005) stated that in order to increase competitiveness, improve the quality of products or services, reduce the costs, and others related to the business for SMEs, the information technology is one of the most effective tools to be adopted and applied. Moreover, if the strategy business planning can be executed in harmony and in line with the strategic planning of information systems/information technology (IS/IT).

\subsection{Strategic Business Plan}

In his article, Curtis (1983) defined strategic business planning as a process in which a company prepared to maintain position or competitiveness in the market. Strategic business planning aims to formulate long-term goals and strategies of the organization or company through the testing on organization in a wider perspective on the environment of competition. On the other hand, McNurlin, et al. (2009) in Pollack, AJ (2010) stated that the strategy indicates the direction in which the company will run or operate and how or with what way the company achieve its goals. In this process, Pearson \& Saunders (2010) explained there were three elements that must be considered in order to run the company's strategic business planning, namely: 1) business strategy begins with a mission and coordinated by a set of activities to achieve the desired goals and objectives with a number of limitations (resources) which are held for the purposes why the business is established; 2) anything in relation with the organizational strategy, work processes, structures, procurement (resource) and a plan that allows to achieve the objectives of the company; and 3) information system strategy that is a plan of an organization to use the information services available.

What is expressed in those studies provide a simple conclusion that to be successful, the company needs a way, techniques, procedures, tactics and strategy that begins with careful planning. Technically, SMEs have a situation, conditions and equal opportunities with large companies (Bamberger, 1989; Aaker, 1989 in Tan, et al., 1995). Both should be able to fulfill what is expected by consumers toward products or services offered and give satisfaction to consumers or customers. Bhabuta (1988) also mentioned that in order to be successful, SMEs do not have to always be worried unable to compete with large companies because of technological backwardness, but the most important is how SMEs can arrange business strategy that is always in tune with the development of technology, and putting these technologies into the appropriate operation with their business.

\subsection{Strategic Information Systems and Information Technology Planning}

The establishment of the IS/IT planning by the company depends on how much the value of the benefits will be obtained by the company and the level of urgency for the achievement of corporate goals. In particular company, IS / IT planning is a very important activity and strategic, whereas for other companies it is not something crucial and become a decisive policy and strategy for the company. Ward \& Peppard (2003) described how environmental of IT strategy is affected by the pressure out of organization control in the form of a two-dimensional matrix, namely infusion and diffusion. According to both, infusion is the organization's level of dependence on the IS/IT in its business, whereas diffusion is the rate at which the IS/IT entrenched in the organization and the decisions relating to its use has shifted. There are four quadrants that occur from infusion-diffusion matrix as shown in the Figure 1 below. 


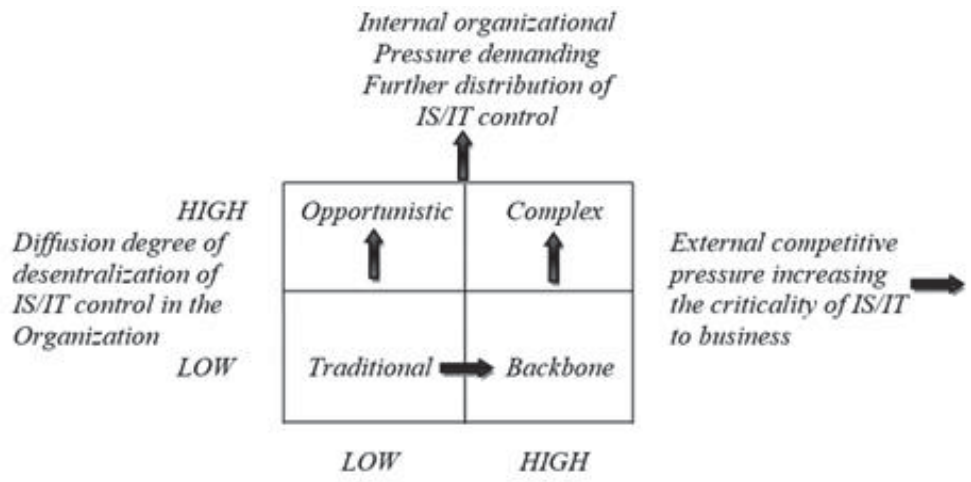

Figure 1. IS/IT environment (Ward \& Peppard, 2003)

a) On diffusion-infusion low (LOW-LOW), the resource control of information technology (IT) is centralized so that the information systems (IS) is not important to the business. This quadrant is called Traditional where companies use IT just to increase its efficiency by utilizing IS as a system-by-system separately. The company in this quadrant run its business management amicably, where the use of IT only as a tool to support business, for example SMEs.

b) At diffusion high-infusion low (HIGH-LOW), IT is very high centrally controlled and IS is treated very importantly in the IS operational and business. Business will not benefit if the IS fails. IS becomes part of the backbone of organization. For instance, company with centralized banking system, where business processes and corporate profits are very dependent on the operational capability of IT. Whereas IS supports in fulfilling the availability of information for companies and customers in a non-stop 24 hours $\times 7$ days as well as services, such as online transaction ATM facilities.

c) On low infusion-high diffusion (LOW-HIGH), IT is controlled decentrally so managers can implement local priorities. Integration of IS occured due to the cooperation among users, not because of the design of a business or IT as a whole. Opportunistic management approach takes the existing opportunities and driven by short-term priorities that can create business advantage in some fields. In this quadrant, IT is still as a supporter, while the management of IS depends on each unit, for example, a franchise company that sells a business system that is supported by the use of IT as a mini market (WalMart, Indomart), property companies (LJ-Hooker, Raywhite ), fast food (McDonald's, KFC).

d) At infusion-diffusion high (HIGH-HIGH), the control system is decentralize, but to achieve the success of the business depends on IT. Both were taken to avoid losses and achieve overall business goals, so it is described as a complex environment and relatively complicated management. In this quadrant companies need the IS/IT strategic and high potential to anticipate the changes that occur. Companies that are in this quadrant is the holding company which has a large range of businesses, complex and wide because it consists of several branches or subsidiaries, as well as its geographical location is in the city traffic, inter islands and even across the country, such as Toyota, IBM, etc.

\subsection{Strategic Business Plan Metodology through Information Systems}

Wang, et al. (2011) gave a weak spot assessment of strategic business planning done by SMEs that for the majority of SMEs' owner-executors, what is obtained in the performance of its business, there may have a shift of its business goal which is to become more dominant in the fulfillment or personal purposes (usually primary) i.e. autonomy, personal satisfaction, and lifestyle. For some firms strategic business planning may have little value added to the success of the company. For this case Wang, et al. (2011) suggested the importance of motivation and aspiration of SMEs' ownerexecutors whether strategic planning is necessary for their business. Robinson \& Pearce (1984) in his studies suggested that for effectiveness in strategic planning, structure of the SMEs should be directed to the short time horizon (about 2 years), and the process should not be too formal, sophisticated and spend a lot of time.

In their study, Wang, et al. (2011) described weaknesses and lacks of SMEs in the preparation of a strategic business plan as shown in Figure 2 below. 


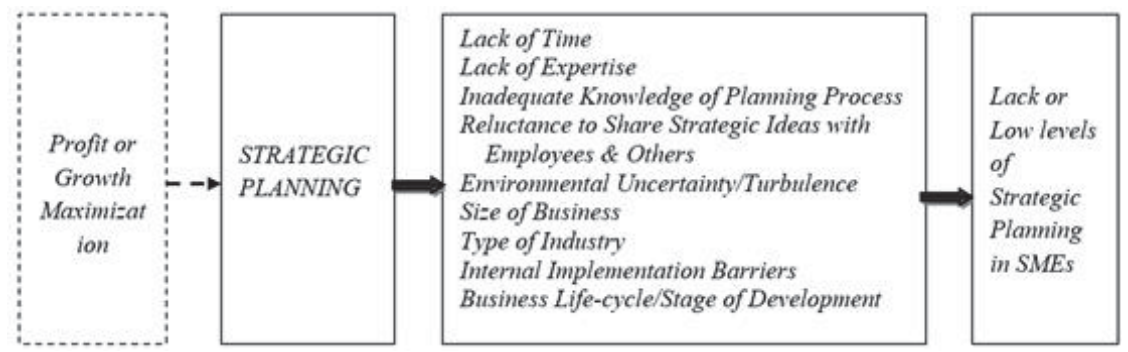

(Wang, 2011)

According to Wang, et al. (2011) weaknesses or lacks of SMEs in making strategic business planning can be seen from the problems that occur at the level of the organization/company (different at the individual level) and approach implicitly which assumes that the company's goal is to maximize profits or business' growth. This means that there is a fundamental problem of what is meant by a 'simple' and a 'very complicated' in making strategic business planning for SMEs. That the success of SMEs in the operations can be determined on an individual level that is the owner-manager and the magnitude of the motivation of the owner-manager is to achieve its business objectives, but not solely for the purpose of maximizing profits or growth of firms. For this situation, Wang, et al. (2011) then proposed a scheme that can be recommended for SMEs in strategic business planning as shown in Figure 3 below.

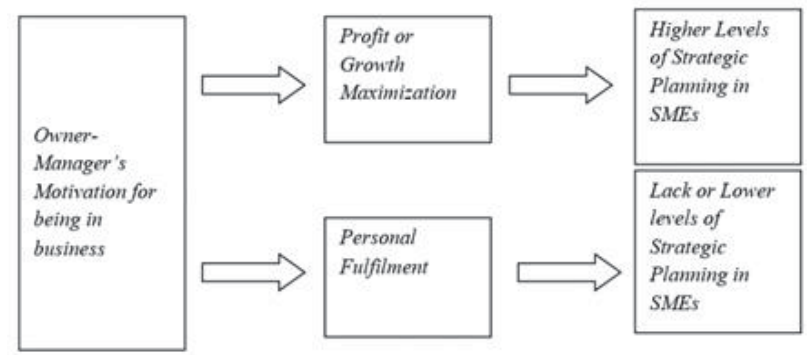

Figure 3. Proposal to explain the weakness and lack in preparing strategic business plan done by SMEs (Wang, 2011)

Figure 3 above explains that the majority of SMEs operate as an 'extension' of the owner-manager. According to Mintzberg (1984) in Shepherd \& Wiklund (2005), the actions and decisions made in the range of SMEs owner-managers is that 'the purpose of the company is the owner-manager objectives, vision and strategy of the company is the vision and strategy of the owner-manager'. Therefore, the strategic vision of the company has a close relationship with the motivation and personal ambitions of the owner-manager. Motivation and personal ambition can be influenced by education level, gender, ethnicity, social marginalization, family commitments, personal aspirations or other considerations viewed in psychological, sociological, demographic and environmental perspectives (Beaver \& Jennings, 1995).

Thus on SMEs, initial initiative and motivation of the owner-manager to run the business is determined by whether the owner-manager will pursue maximum profits or growth, or will improve his personal fulfillment. Whichever option taken will affect and determine business strategy.

\subsection{Role of social network in SMEs business}

The use of pages (web/website) and social networking in the community or businesses in developed countries has been accounted by Goad and Mooney (2008) in his study. There were three of the most popular in the UK, Facebook have been used $55 \%$ as social media that was able to take market share of $38 \%$ Internet users, $10.5 \%$ of Youtube and $2 \%$ of Twitter. However, Ballocco, et al. (2009) has observed 646 of SMEs in Italy found that the use of Mobile Internet (IM) in the country was still very limited. The reason is the lack of knowledge of the technology developed at that time and have not felt the benefits and value that would be obtained if adopting that technology.

Recent development of Facebook users are presented based on data from socialbakers.com showed the percentage of Facebook users worldwide was 44.97 per cent in North America, 29.96 percent in Europe, 33.92 percent in South America, 42, 14 percent in Australia and Oceania, 6.68 percent Asian, and 5.15 percent in Africa 
(http://www.socialbakers.com). While in Indonesia, data of social network users (in this case Facebook) on December 31, 2011 showed that there were 51,096,860 users have owned Facebook or $20.6 \%$ penetration rate of the Indonesian population of which nearly 250 million people (http://www.internetworldstats.com / asia.htm). That was just one-fifth of the population of Indonesia who use social networking for business activities. Meanwhile, Internet users in Indonesia until the end of 2013 noted 63 million people, ranks fourth in the world after the US, Brazil and India, where its 95\% is used to access social networking (www.webershandwick.asia).

In developing countries, especially in Southeast Asia, Omar, et al. (2011) conducted a study of 200 SMEs in Penang, Malaysia associated with the web-based marketing applications and found that the majority of SMEs in Malaysia which utilize IT for their business was still limited to the use of email and static pages, while the online payment system, processing orders online, moreover the use of social networks such as Facebook for business development was still relatively low. Omar, et al. (2011) also stated that an understanding of the benefits to be gained when adopting the technology was still low. More than 50\% of SMEs were not aware that the web-based marketing will improve the performance and profitability of the company, increasing the ROI (Return On Investment), reduce operational costs and improve business process flow. On the other hand, the issue of technical security and privacy in adopting these technologies by SMEs in Malaysia became part of the most interesting to study.

Situations of SMEs in Malaysia is not much different from the existing SMEs in Indonesia. Studies on the use of information technology in 94 SMEs in Jepara (Roosdhani, et al., 2012) and 23 SMEs that were under development by LPB Joint-Venture Institute of Technology, Surabaya (Sari \& Hanoum, 2012) showed that the use of social networking and moreover to support the improvement of the performance of SMEs was still relatively low. The motivation for adopting the technology was actually quite high but constrained financial problems, infrastructure, and human resources to handle it. Also uncertain situation whether the investments will be able to add value and benefit to the company.

\section{Research Framework}

The framework on this study will refer to and modify the model to strategic business planning conducted by Wang, et al. (2011) and involves variables that affect motivation and personal ambition proposed by Beaver and Jennings (1995), but will focus on the involvement of social networking as a means to achieve the success of strategic business planning for SMEs. The diagram on the conceptual framework of this study can be explained in Figure 4 below.

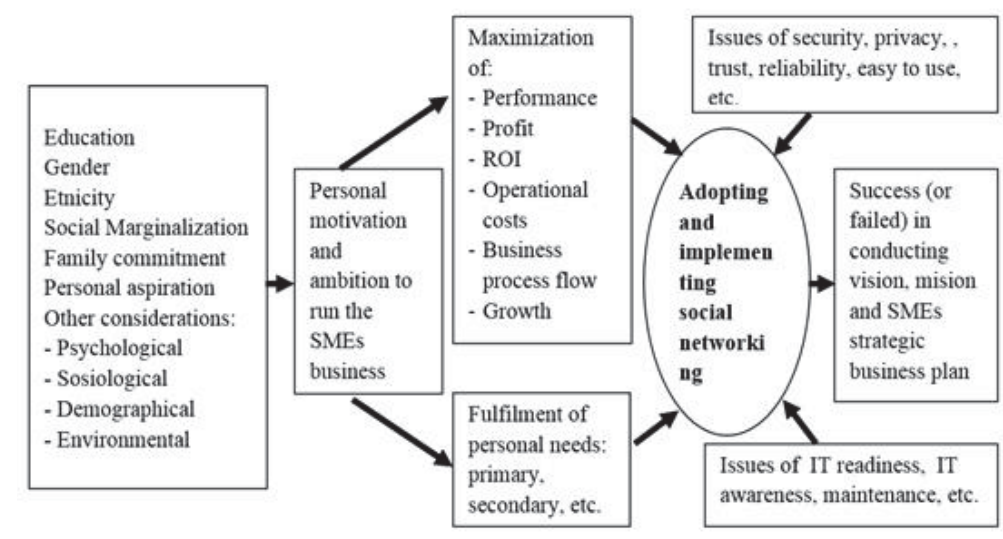

Figure 4. Research framework

\section{Research Methodology}

This study was designed in the form of experimental study of One-Group Pre-test Post-test design which takes approximately 6-12 months to collect data and information in the field. In this experiment every SME as research sample was observed and tested before and after a treatment provided, and subsequently its results recorded. Treatment as independent variables, whereas the results as dependent variable. The figure below shown the experimental process for this study (quoted from Ertambang Nahartyo, 2013, p. 85). 


\section{$\mathrm{O}_{1} \mathrm{X} \mathrm{O}_{2}$}

Figure 5. One-Group Pre-test Post-test Design Experiment

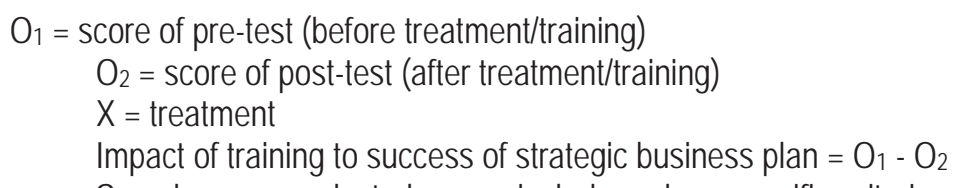

Samples were selected purposively based on specific criteria or reasons that are considered to represents the population. The target of sample is approximately 25 to 30 pieces of SMEs (in the form of community / associations, clusters, cooperatives or business / similar business centers) that exist in the study area and represent each district in former Surakarta recidency. There were 6 districts and 1 municipality in this location, or about 4 to 5 SMEs per district which have business in garment, home industries, agricultural/plantation commodities, metal craft, clay, food and beverage businesses, or other products as samples in this study.

The instrument used in this study are:

1) In-depth interviews both toward the chairman of the association/cluster/ cooperatives/group of similar business and with artisans directly in the field to collect data and information relating to the issues that (may) encountered so far.

2) Discussion groups (focus group) or forum of a question and answer at a meeting with members of the association/cluster/cooperatives/business centers to supplement and cross-check the data and information obtained previously with their chairman.

3) List of questions in the form of open and closed questionnaire distributed to the chairman and members of the association / cluster / cooperatives / associations / business centers to explore deeper into the data and information relating to aspects of the input, process and output as well as internal and external issues that (may) happen during this time.

Generally, this study is analyzed both qualitatively and quantitatively in order to obtain optimal results. For qualitative analysis, SWOT analysis (Strengths, Weaknesses, Opportunities, Threats) is used to map the problems occurred by viewing of strengths and weaknesses owned by SMEs, opportunities and challenges or threats faced by SMEs and the potential that can be raised and developed related with strategic business planning on SMEs. Whereas for quantitative analysis, GSCA analysis (Generalized Structured Component Analysis) is applied to accomodate the variables involved in this study and to explore the correlation and the influence among variables. GSCA is a multivariate analysis to observe the characteristics of an object of research conducted simultaneous/concurrent and has relationships between variables that are observed simultaneously (Hwang, et al., 2010).

\section{Research Findings}

The data and information obtained from the field which is conducted by interviews, group discussions, and distributing questionnaires to research samples provides descriptive results as follows.

1) Location of the municipality of Surakarta

a. Of the three samples of research, the issue of financing/capital cannot be avoided, but due to the location of sample is in the city, then other funding agencies can be available many more. However, the more urgent is the ability of SMEs in managing finances, making bookkeeping, preparing financial statements, and other related matters seems not perform well, organized and systematic. Utilization of information technology is also still not optimal yet.

b. From the aspect of production, three samples showed the good performance because it is an area of their expertise. The problem lies in the productivity and the ability to fulfill orders in large amount from prospective buyers. Unfulfilled orders will have a sub-contract to other SMEs which are willing and able to deal with the consequences of inconsistent quality.

c. Marketing for batik products, culinary and furniture is not a problem for SMEs since its duties are only fulfill orders from prospective buyers who own big capital or merchants, but it will be a constraint if SMEs should seek buyer candidates by their own way. 
d. Low quality of human resources due to the disparity on the class of economic, social and educational found in the samples. Work stimulation and motivation to become craftsmen of SMEs are also relatively low because they do not be provided career advancement opportunities, income and life assurance. Being a craftsman of SMEs is considered only to survive in the city, look for additional income, or just spend leisure time.

e. Transport and telecommunications infrastructure in urban areas is relatively better than in suburban or rural. Nevertheless, the use of the Internet and mobile phones to support the business activities of SMEs are still few and not optimal. Internet and mobile phones are only used for general purposes such as sending sms, chat, and browsing.

2) Location of the district of Boyolali

a. Of the three sample locations, crucial issue regarding the financing is that to buy the raw materials is difficult to obtain. If it can get then the raw materials will be expensive, if there is no funding sources then the raw materials are not available`.

b. Production and productivity in all samples is low because the production process using the traditional method, the equipment used is simple, and not enough capital available, especially to fulfill large orders.

c. Lack of knowledge and information led to the SME market is very dependent on a third party/capital owners/merchants who have a shop or gallery. In addition, to get in the market is also relatively limited because of the lack of ability to sell their products. Also stiff competition among SMEs to get prospective buyers who come to the business location directly or through intermediaries. The use of down-payment is sometimes not enough to buy raw materials or only fitting to cover the cost of production.

d. The low of education and lack of expertise/skills become issue of poor quality of human resources. The enthusiasm and interest in the community of productive age to become artisans/entrepreneurs of SMEs is not so much because be a civil servant or private/factory worker provides more guaranteed salary, career and future.

e. Technology used by SMEs is very common due to continuing the tradition of ancestor who taught for generations. Some existing SMEs have and use the Internet to create a page (website), but cannot be empowered optimally because of physical constraints (Internet network), human resources who handle the technology as well as English language skills for media communication with buyers from overseas.

3) Location of the district of Sukoharjo

a. There are five clusters/associations of SMEs become research samples in this area. The problem of capital becomes a classic issue, particularly for the procurement of raw materials. Financing for the procurement of raw materials by SMEs to the supplier can be done through three ways, namely cash to get supplies from suppliers in Surabaya, credit to local suppliers (in a cluster) and the 3-day term of up to 3 months if using services exporter.

b. Constraints scarcity of raw rattan or wood which must be imported from outside the island of Java, sometimes have to use illegal way (smuggling), which causes extra cost. For ordering in large quantities, the productivity usually low due to limited production capacity and weak managerial capacity, low quality of human resources and lack of marketing media.

c. In terms of marketing, SMEs' competitive power is low compared to similar industries from other regions. Quality of products which are marketed abroad is also low due to the low quality of human resources of SMEs particularly in terms of processing products, such as furniture. Lack of promotional programs has made products such as furniture actually better known in foreign markets than at home country.

d. Lack of training and skills of workers in SMEs makes product quality does not meet the standards as done by less skilled labor.

e. The use of simple technology with old equipment, lack of waste management of production, poor waste disposal installations (e.g. dye), inadequate sewage treatment is a problem that is encountered on the samples in Sukoharjo. Some existing SMEs already have their own website, but not yet used optimally to support their business.

4) Location of the district of Karanganyar

a. Financial problems on three samples in this location do not exist because the scale of business is relatively small. The tourism business is managed and become the responsibility of Regional Government so the role of SMEs is just complementing the accommodation of the sites, for instance food court, vending souvenirs, tour guide, and so on.

b. Aspects of production on the industrial medicinal constrained by the drying process (herbal pieces) that 
depends on the intensity of sunlight. Under conditions of excess production, the use of sunlight becomes ineffective. Drying machine provided by the Local Government is also too wasteful of energy generator (electricity, gas) and its use is inefficient (production slightly, engine capacity is too big), so the machine be terminated.

c. On tourism SMEs, marketing promotions conducted by the Regional Government, whereas on SMEs medicinal herbs promotions carried out in collaboration with the medicinal herbs' company namely Sidomuncul, Semarang, meanwhile on SMEs Batik Girilayu left entirely to batik entrepreneur who is also as relatives of the palace of Mangkunegaran.

d. A similar concern with respect to human resources with SMEs in other districts is low quality of product caused by low education and little motivation to work or do business on SMEs.

e. The technology used in SMEs medicinal herbs uses sunlight, while SMEs Batik Girilayu still use traditional means for holding the tradition which passed down from the palace Mangkunegaran. On the other hand, tourism SMEs already have a page (website) but in the form of static website (not dynamic) so it cannot make direct communication with visitors of the page (website).

5) Location of the district of Wonogiri

f. At the five samples in this region, the issue of capital is a common problem. Some SMEs are able to meet the international market such as SMEs who produce seaweed, buyers demand from China and Taiwan is quite high but constrained by the problem of funds, while the role of Local Government merely provide guidance. As a result, several cost components should be treated by SMEs themselves before being sent abroad, for example the cost of labor, packing, shipping, and so on.

g. Production processes in SMEs cashew, cassava, agate and furniture are still using traditional methods with simple equipment.

h. For the marketing of products such as cashew, seaweed and cassava SMEs is quite able to meet demand from overseas buyers. In conditions like this sometimes price factor becomes a problem because overseas buyers then set the price for the SME market.

i. Low quality of human resources due to economic crisis, social affairs and education problems. Also, mentality of society, especially those of productive age has low motivation for entrepreneurship or continues his/her parents business. Limited availability of educational facilities, transport and telecommunications infrastructure is not sufficient and is also an obstacle to their development.

j. Technology to help SMEs has not been run optimally because one of the requirements cannot be met, for example, production of cassava can be processed into bio-ethanol as an alternative fuel. A company of China intends to build an ethanol plant in Wonogiri, but it has canceled that project due to the availability of water as a requirement cannot be met. Information technology and mobile phones cannot be fully exploited due to the constraints of land contours in Wonogiri region which is hilly.

6) Location of the district of Sragen

k. Financial problems in the five samples showed that craftsmen of SMEs is placed as a party that needs to be assisted financially in order to produce needed goods for the third party e.g. owners of capital or merchants. As a result of this situation, craftsman became 'bound' to thrive financially because their needs have been fulfilled by those third parties.

1. No technical obstacle on the samples because of what has conducted was a hereditary tradition. It could say artisans/entrepreneurs of SMEs in the Sragen regency has had advanced skills even in SMEs Batik there is a specific uniqueness in production process where the dye material is taken from natural materials such as banana leaves for green color, teak leaves for red color, and so on.

$\mathrm{m}$. Some SMEs be quite overwhelmed to fulfill orders, especially from overseas buyers, such as weaving sarung goyor buyers from Somalia, Africa. Its main constraint is the limited number of craftsmen available and willing to be involved when necessary to fulfill the order anytime.

n. The enthusiasm and interest of the community of productive age to be a craftsman of SMEs are still relatively low because there are other more promising alternatives, such as a factory worker or civil servants. As consequence, craftsman of SMEs are forced to reduce its production capacity rather than unable to meet the market demand.

o. Technology used to produce SMEs' goods is still quite traditional and simple namely ATBM (traditional equipment) to produce weaving sarung goyor. On the other hand, the use of information technology such as Internet is also not much. If there are, it is usually a large-scale company and is able to export their goods abroad, e.g. furniture producers. 


\section{7) Location of the district of Klaten}

p. Viewed from the availability of capital, the three samples in research area strive to fulfill their own capital needs or get help from various sources, either from the Local Government (APBD), the Central Government (APBN) or from other financial resources (e.g. banking, the International Organization for Migration and the Java Reconstruction Fund).

q. Most of SMEs in Klaten use traditional ways to generate their products as a form of preservation of the cultural values from their ancestors.

r. Marketing products on SMEs in Klaten partly done by third parties/vendors, such as artisans/entrepreneurs pottery and ceramics in Melikan, but others are done by themselves.

s. In Klaten there is a vocational school that educates students to be able to make batik so that future generation of batik craftsmen can keep be existed in Klaten. Nevertheless, ratio of craftsman who is needed to fulfill the demand product is still unbalanced, meaning there is not many productive age groups who have interest or desire to become craftsmen of SMEs. They prefer to be a factory worker rather than craftsmen of SMEs.

t. The technology used to make batik, striated and pottery/ceramics is still quite traditional with simple equipment. This is to continuing the tradition that has been passed down through generations, where batik or striated is produced using handmade to give the feel of originality rather than using the weaving machine.

\section{Conclusion}

Of what are obtained in the field with respect to the sample of SMEs in 6 districts and 1 municipality in former of Surakarta residency showed that nearly in all sample sites, the classic problem such as limited financial resources, infrastructure especially telecommunications and transportation, marketing mainly to promote SMEs products, human resources involved in the business process especially with respect to the quality of work and the availability of manpower/craftsmen, as well as information technology used has not been utilized optimally. Not only SMEs in rural regions, but also in the city or suburbs, those problems are still difficult to avoid, especially in developing countries.

The potential of information technology to be adopted and applied by SMEs has not been utilized optimally. Although some SMEs already have a page (web), but is still limited to be used as a mere completeness, except pages owned by the Local Government. Obstacles on geographic location, transportation and telecommunications become a very important issue to note all parties involved in the management of SMEs. The role of Local Government/City and the ranks of organization unit should be intensive and pro-active in providing facilities and infrastructure, including the aspects of education and skills for SMEs to prepare labor which has high quality and dedication to guarantee that the SMEs business runs well and keep exist in the future.

The findings is also supporting of what has been stated by Roosdhani, et al. (2012) and Sari \& Hanoum (2012) that the use of information technology, especially social networking, by SMEs in Indonesia to improve the SMEs' performance is still relatively low due to several constraints both physical such as infrastructure, financial, human resources, marketing, production and non-physical such as management, strategy, bureaucracy, policy, and so on.

\section{Research Limitation}

Because this study is experimental and takes 6-12 months to explore comprehensively, i.e. identifying the problems occurred, finding its causes, providing a treatment in a particular form of training, then observing and analyzing what happened before and after treatment, and finally proposing a model or framework on the SMEs regarding the use of social networking for strategic business planning, it is necessary to do further research.

This research report is presented as the first part of two parts, where in this first part attempts to identifying the problems that occur and the potency of information technology in supporting SMEs to make strategic business planning. Whereas in the second part sought to provide further analysis to understand the correlation and the influence amongst variables which is involved in this research. Therefore, the deeper discussion is necessary to explore whether the proposed model in this research is suitable for SMEs which implement social networking for their strategic business planning. 


\section{References}

Aaker, D. A. (1989). Managing Assets and Skills: The Key to a Sustainable Competitive Advantage. California Management Review, pp. 91-106.

Atmaja, Wahyu H. K., M. Kom. (2002). Tesis: Penyusunan Metodologi Perencanaan Strategis Sistem Informasi Berbasis Value Bisnis (Be Vissta Planning) dalam rangka Meningkatkan Peran Strategis Sistem Informasi pada Suatu Organisasi. Magister Teknologi Informasi, Program Pascasarjana, Fakultas Ilmu Komputer, Universitas Indonesia, Jakarta

Baets, W. (1992). Aligning Information System with Business Strategy, Journal of Strategic Information System, September, Vol. 1, No. 4.

Ballocco, R., et. al. (2008). Mobile internet and SMEs: a focus on the adoption. Industrial Management \& Data Systems, Vol. 109 No. 2 , pp. 245-261

Bamberger, I. (1989). Developing Competitive Advantage in Small and Medium-Size Firms. Long Range Planning, Vol. 22, No. 5, pp. 80-88.

Beaver, G. \& Jennings, P. (1995), 'Picking Winners: The Art Of Identifying Successful Small Firms', in DE Hussey (ed.), Rethinking Strategic Management, John Wiley and Sons Ltd, pp. 91-106.

Bhabuta, L. (1989). Sustaining Productivity and Competitiveness by Marshalling IT. Information Technology Management for Productivity and Competitive Advantage. IFIP TC-8 Open Conference, Singapore.

Boulcomb, J. S. (2003). Management of Change through Force Field Analysis. Journal of Nursing Management, Vol. 11, pp. 275-280.

Brumec, J. \& Vrcek, N. (2002). Strategic Planning of Information Systems (SPIS): A survey of methodology. Journal of Computing and Information Technology, CIT 10, pp. 225-231.

Cheng, L. C. (1990). Strategic Management for Small and Medium Enterprises in Singapore, National University of Singapore.

Curtis, D. A. (1983). Strategic Planning for Smaller Businesses, D.C. Heath and Company, Canada.

Earl, M. J. (1993). Experiences in Strategic Information Systems Planning. MIS Quarterly, 17(1), pp. 1-24.

Ghazi, A. \& Khalid, A. (2012). E-Business Enablers and Barriers: Empirical Study of SMEs in Jordanian Communication Sector, Global Journal of Business Research, Vol. 6, No. 3.

Griggs, K. A. \& Wild, R. (2012). A model for the Adoption of Social Networking Applications in Organizations, International Journal of Arts \& Sciences, UniversityPublications.net

Goad, R. \& Mooney, A. (2008), The Impact of Social Networking in the UK, Hitwise/ Experian Report, New York, NY

Harris, L., et.al. (2012). Punching above their weight: the changing role of networking in SMEs. Journal of Small Business and Enterprise Development, Vol. 19 No.2, pp. 335-351

Hartono, E., et. al. (2003). Key Predictors of the Implementation of Strategic Information Systems Plans. The DATA BASE for Advances in Information Systems, 34(3), pp. 41-53.

Hourali, M., et. al. (2008). A Model for E-readiness Assessment of Iranian Small and Medium Enterprises, Journal of Faculty of Engineering, Vol. 41 (7), pp. 969-985.

Hovelja, T., et. al. (2010). Measuring SISP success in enterprise in Slovenia. Management, Vol. 15, 2, pp. 25-46

Hwang, H., et.al. (2010). Generalized Structured Component Analysiswith Latent Interactions. Psychometrika, Vol. 75 No. 2, pp. 228242.

Imelda (2008). Penerapan Metodologi Be Vissta Planning pada Konsultan Teknik dan Manajemen Studi Kasus PT. Virama Karya, Konferensi Nasional Sistem dan Informatika, Bali.

Kau, A. K. (1988). Business Practices of Small and Medium Enterprises in Singapore, Singapore.

King, W. R. (1984). Evaluating an Information Systems Planning Process, Working Paper \#592, Graduate School of Business, University of Pittsburgh.

Lederer, A. L. \& Sethi, V. (1988). The Implementation of Strategic Information System Planning Methodologies, MIS Quarterly, September, Vol. 12, No. 3.

Lewin, K. (1951). Field Theory in Social Science, Harper Row, London.

Livingston, A. D., et. al. (2001). Root causes analysis: Literature Review. WS Atkins Consultants Ltd, Birchwood Boulevard, Warrington.

Martin, E. W., et. al. (2005). Managing Information Technology, fifth edition, Pearson-Prentice Hall, Pearson Education Singapore, Pte. Ltd., pp. 561-562

Martin, J. (1989). Strategic Information Planning Methodologies, 2nd edition, Prentice-Hall.

McNurlin, B., et. al. (2009). Information Systems Management in Practice, 8th Ed. Upper Saddle River, New Jersey: Prentice Hall.

Omar, A., et. al. (2011). Determining Factors for the Usage of Web-Based Marketing Application by Small and Medium Enterprises (SMEs) in Malaysia. Journal of Marketing Development and Competitiveness, Vol. 5(2), pp. 70-86.

O'Regan, N. \& Ghobadian, A. (2002), 'Effective Strategic Planning in Small and Medium Sized Firms', Management Decision, 40 (7), 663-671.

Pavlou, A. P. \& El Sawy, O. A. (2006), From IT Leveraging Competence to Competitive Advantage in Turbulent Environments: The Case of New Product Development, INFORMAS: Information Systems Research.

Pearlson, K. \& Saunders, C. (2010). Managing and Using Information Systems: A Strategic Approach, 4th Ed. Hoboken, New Jersey: John Wiley \& Sons, Inc.

Piccoli, G. (2008). Information Systems for Managers: Text \& Cases. Hoboken, New Jersey: John Wiley \& Sons, Inc.

Pollack, T. A. (2010). Strategic Information Systems Planning. ASCUE Proceedings. 
Porter, M. E. (1998). Competitive Strategy: Techniques for Analyzing Industries and Competitors. The Free Press, New York.

Porter, M. E. \& Miller, J. E. (1985). How Information Gives You Competitive Advantage. Harvard Business Review. July-August edition.

Rackoff, N., et. al. (1985). Information Systems for Competitive Advantage: Implementation of a Planning Process," MISQuarterly ( 9:4), pp. 285-294

Robinson, R. B. \& Pearce, J. A. (1984). Research Trusts in Small Firm Strategic Planning. Academy of Management, 9 (1), pp. $128-137$.

Rockart, J., et. al. (1985). Engaging Top Management in Information Technology. Sloan Management Review (25:4), pp. 3-16.

Roig, R. A. \& Schneider, P. (1994), Audits and Root Cause Analysis, Total Quality Environmental Management, V4nl, pp: 67-74, Wiley \& Sons, Inc.

Roosdhani, M., R., et. al. (2012). Analisis Tingkat Penggunaan Teknologi Informasi dan Komunikasi pada Usaha Kecil Menengah di Kab. Jepara. Jurnal Dinamika Ekonomi \& Bisnis, Vol. 9 No. 2, pp. 89-104

Sari, R., M. \& Hanoum, S. (2012). Analisis Faktor-faktor yang Mempengaruhi Penggunaan Internet terhadap Peningkatan Kinerja UKM Menggunakan Metode Structural Equation Modelling. Jurnal Teknik ITS Vol. 1, pp. 488-493

Shepherd, DA \& Wiklund, J 2005, 'Entrepreneurial small businesses: A Resource-Based Perspective', Edward Elgar Publishing Ltd, Cheltenham.

Tan, C. S., et. al. (1995). Guidelines for Strategic Information Systems Planning in Small and Medium Enterprises, PAC/S (Proceedings).

Tandjung, J. W. (2011). 18 Jurus Ampuh Menyiasati Persaingan Bisnis. Andi Publisher: Yogyakarta.

Tozer, E. E. (1996). Strategic IS/IT Planning. Butterworth-Heinemann, Boston.

Wang, C., et. al. (2011). Explaining the Lack of Strategic Planning in SMEs: The Importance of Owner Motivation. Edith Cowan University Research Online, ECU Publications.

Ward, J. \& Peppard, J. (2002). Strategic Planning for Information Systems, thirth edition, John Wiley \& Sons, Ltd.

Webster, J., et. al. (1989). The Manager's Guide to Strategic Planning Tools and Techniques, Planning Review, Vol. 17, No. 6, pp. 4-13.

Wetherbe, C. \& Davis, G. B. (1982). Strategic Planning Through Ends/Means Analysis. MIS Research Center, Working Paper, University of Minnesota.

Wijaya, A. F \& Manongga, D. (2012). Information Systems Strategic Planning to Increase Competitive Advantage of Higher Education Using Be Vissta Planning Methodology (Case study: SWCU Salatiga). The International Journal of Organization Innovation, vol. 5, num. 2, Fall.

$\mathrm{Yu}$, Chien-Chih (2007). A value-based strategic management process for e-government strategy planning and performance control. Proceedings of the 1st International Conference on Theory and practice of electronic governance, ACM, pp. 169-178.

Boyolali Dalam Angka 2014. BPS Kabupaten Boyolali, 2014

Karanganyar Dalam Angka 2014. BPS Kabupaten Karanganyar, 2014

Klaten Dalam Angka 2014. BPS Kabupaten Klaten, 2014

Sragen Dalam Angka 2014. BPS Kabupaten Sragen, 2014

Statistik Daerah Kota Surakarta 2104, BPS Kota Surakarta, 2014

Sukoharjo Dalam Angka 2013. BPS Kabupaten Sukoharjo, 2013

Wonogiri Dalam Angka 2014. BPS Kabupaten Wonogiri, 2014

http://www.internetworldstats.com/asia.htm. Accessed on 11 March 2014

http://www.rocket-internet.de. Accessed on 13 March 2014

http://www.webershandwick.asia. Accessed on 11 March 2014

http://www.firstfocus.eu/blog/social-media-in-developing-countries. Accessed on 10 March 2014

http://www.socialbakers.com. Accessed on 10 March 2014 
